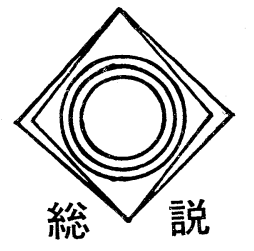

\section{ビル暖冷房の動向と将来}

-1980.8 .28 受理一

\section{1. 進駐軍施設工事で開幕した戦後の建築設備}

“連合軍の日本各地への進駐により一時その影を潜 めていた暖房工業は, 幾年振りかに活沉を呈し, 昨年 末より本年(昭和 21 年)にかけて, あたか子戦争中の飛 行機製造工業の如き黄金時代を出現した観がある”(衛 生工業協会誌第20巻第9-10号) これは, 服部功氏が終 戦の翌年である1946年に投稿した論文の一節である。

このように, 戦後のわが国の建築設備は, 進駐軍施 設の工事でその開幕を迎えることになる。GHQとな った第一相互 (現第一生命ビル)をはじめとする接収 建物の改修工事, キャンプ, デペンデント・ハウス, アパートなどの建設が，1946年から1949年にかけて関 係者の異常な努力によって遂行されて行った。これは まさに, 戦後にまで継続された軍需景気でもあった。

これらの進駐軍施設工事の実施には, 多くの設備技 術者を必要とし，この期間に米軍仕様による設備技術 を習得した技術者が多く，その後のわが国の建築設備 の発展の方向に大きな影響を与えることになってく る。

井上宇市早大教授（前空気調和・衛生工学会長）は わが国の明治以来の建築設備を，摇らん期（明治初期 から第 1 次世界大戦) ・ 成熟期 (昭和 $5 \sim 16$ 年) ・ 復興 期 (終戦から沼和 30 年) ・ 躍進期 (昭和 30 年以降) に分 類している。この分類に従えば, 第 2 次世界大戦前, わが国の空調設備は成熟期にあり，その技術はすでに 国際水準に達していたものと考えることができる。そ のため, 戦中の技術の空白, 戦後の破壊的な経済状態 にもかかわらず，10年たらずの復興期により，その技 術は再び国際水準への復帰が可能だったのであろら。

\section{2. 中央式空調方式の盛衰}

2.1 本格的空調インダクション・ュニット方式の 登場と衰退

戦後初の本格的なオフィスビルとして「ブリヂスト ンビルディング(1951年)」が竣工したのは，戦後も落

東京都文京区後楽1-4-27
株式会社 日建設計 石 福昭

ち着きを取りもどした 6 年目のことだった。この建物 の空調設備には，当時最新鋭の方式とされたインダク ション・ユニット方式（松田・平田建築設計事務所設 計）が採用されている。以後,「日活国際会館（1952 年)」，「大正海上火災ビル（1963年)」など，わが国の 高級オフィスビルには，インダクション・ュニット方 式が相次いで採用された。わが国初の超高層ビルであ る「霞ケ関ビル（1968年)」，引き続いて竣工した「神 戸貿易センター（1969年)」，「世界貿易センター(1970 年)」などの超高層オフィスビルにもこの方式が採用 され，その最盛期を迎えることになる。

空調設備は元来，劇場などを対象とした大空間空調 そ中心に発達してきたものでめる。そのため，小空間 を中心とする事務所建物に対する空調は設計上の重大 な課題であった。そして，その解答として出現したの がインダクション・ニニット方式である。インダクシ ョン・ユニット方式は一次空気（冷風または温風）と 2 次水（冷水または温水）により冷暖房を行ら水空気 方式で，ニニット毎に温度制御が可能なので小空間の 空調に適した優れた方式であった。

インダクション・ユニット方式は，コンジット・ウ エザーマスター装置として1939年, ウィリス・キャリ ア（米国）によって特許が取得されて以来，米国にお いては高層オフィスビルの95\%までがこの方式によっ ているといわれる。しかし，わが国に和いてこの方式 は，「新日鉄ビル（1970年)」，「朝日東海ビル（1971 年)」，「横浜天理ビル（1972年）」，などを最後に，急 速に衰退して行った。この衰退の最大の原因は, 床貫 通ダクトによる防荻上の弱点によるもので，そのほか 個別運転が困難なこと，フィルタ一性能が劣ることな どがあげられている。

表 1 （井上宇市：日本の超高層建築の空調・衛生設 備空気調和・衛生工学，S 49-6）はわが国の代表的な 超高層建物の空調方式を示したものであるが，霞ケ関 ビルより横浜天理ビルに至る前半 9 例の超高層建物の らち,そのペリメータにインダクション・ュニットを 
表 1 代泰的な超高層建物の空調方式

\begin{tabular}{|c|c|c|c|c|}
\hline \multirow{2}{*}{ 建 筑 名 称 } & \multirow{2}{*}{$\begin{array}{l}\text { 嵲 } \frac{T}{\text { 月 }} \\
\text { 年/昭和) }\end{array}$} & \multirow{2}{*}{$\begin{array}{c}\text { 建築高 } \\
{[\mathrm{m}]}\end{array}$} & \multicolumn{2}{|c|}{ 高層階空調方式 } \\
\hline & & & ペリメータ & インテリア \\
\hline 霞が関 ビ ル & $43 / 4$ & 147 & I D & $S D$ \\
\hline 富士フフィルム & $44 / 6$ & 71 & $\mathrm{FC}$ & SD \\
\hline 神戸貿易センター & $44 / 11$ & 107 & I D & $S D$ \\
\hline 世界貿易センター & $45 / 2$ & 152 & I D & $S D$ \\
\hline 新 日鉄 ビ ル & $45 / 3$ & 78 & I D $(3 \mathrm{P})$ & D D \\
\hline 朝日東海ビル & $46 / 7$ & 110 & I D & S D \\
\hline 日 本 I BMビル & $46 / 10$ & 87.5 & F C & $\mathrm{FU}$ \\
\hline NHK放送センター & $47 / 10$ & 102 & $\mathrm{FC}(4 \mathrm{P})$ & $\mathrm{FU}$ \\
\hline 横 浜 天理ビル & $47 / 12$ & 102 & I D & S D \\
\hline 大阪大林ビル & $48 / 1$ & 120 & $\mathrm{~F} \mathrm{C}(4 \mathrm{P})$ & $\mathrm{SD}$ \\
\hline 大阪国際ビル & $48 / 2$ & 125 & F C & S D \\
\hline 東京三和ビル & $48 / 11$ & 100 & $\mathrm{FC}(4 \mathrm{P})$ & $\mathrm{FU}, \quad \mathrm{VAV}$ \\
\hline 東京海上火災ビル & $49 / 3$ & 100 & $\mathrm{FC}(4 \mathrm{P})$ & SD \\
\hline A I U ビル & $49 / 3$ & & S D & $\mathrm{VAV}$ \\
\hline 新宿住友ビル & $49 / 3$ & 200 & $\mathrm{~F} \mathrm{C}$ & FU \\
\hline 新宿三井ビル & $49 / 9$ & 211 & S D & VA V \\
\hline 国際通信センター & $49 / 6$ & 151 & $\mathrm{~F} \mathrm{C}$ & SD \\
\hline
\end{tabular}

注 $\mathrm{SD}$ : 単一ダクト, DD : 二重ダクト, $\mathrm{FU}$ : 各階ユニット, I D : インダクション・ユニット, F C : ファンュイルュニット, $\mathrm{VAV}$ : 可変風量

採用したものが半数以上の 6 例に括よんでいる。一 方，大阪大林ビルより国際通信センターに至る後半 8 例については，インダクション・ユニットの採用を見 いだすことはできない。

\section{2 わが国で独自の発展をとげたファンコイル}

$$
\text { ユニット方式 }
$$

現在，わが国のオフィス空調の主流は，ファンコイ ルニニットカ式でといって異論はないだろう。わが国 でファンコイルニニットが最初に市貼されたのは1941 年で，大阪見本市会館の国際ホテルに，新晃工業によ って納入されている。初期のファンコイルニニット は，軸流ファンを使用した初歩的なものであったが， その後, 急速に改良され, 50年代後半には前節で述べ たインダクション・ユニットの対抗機種としての地位 を徐々に築いていった。

戦後のオフィスビルのひとつの特徴は，全面ガラス に代表される大きな窻であったが，この場合，空面に は，大きな冷暖房負荷が発生し，この負荷を処理する ために空面専用の空調ゾーンが必要となる。この空調 ゾーンはペリメータゾーンと呼ばれ，すでに建築計画 の常識的な用語ともなっているが，事務所建築のペリ
メータゾーンに対するもっとも一般的な空調方式とし て，わが国ではファンコイルユニット方式が一般的に 採用されるよらになったのである。

表 1 の後半8例の $5 ち 6$ 例は, ペリメータにファンコ イルニニットを学採用して, 現在ペりメータ方式の主流 はファンコイルユニット方式であるといえるだろら。

ファンコイルュニット方式は全水方式の空調で，配 管の接繶方法によって 2 パイプ方式, 3 パイプ方式, 4 パイプ方式に分類されている。

2 パイプ方式は，フッンコイルニニットに 2 本の配 管を接続し，喻水をたは温水を送って冷层，暖房を行 ら方式で，ファンコイルニニット方式の基本方式です る。現在，一般に広く普及しているが，一つのゾーン に, 冷房と暖房が混在すると，この両負荷を同時に処 理することができないので，負荷の傾向の複雑な建物 には適さない。このような場合, 次の 3 パイプ方式, 4 パイプ方式が採用される。

3 パイプオ式は, ファンコイルニニットへ冷水と温 水の往管 2 本，還管 1 本, 計 3 本のパイ プが配管さ れ, コイルの入口には冷水と温水を混合する特殊 3 方 弁が取り付けられ，冷房，暖啳の両負荷を同時に処理 
乙得る方式である。しかし，還管が 1 本で冷水，温水 が共用であるために，冷水と温水の混合による混合損 失が大きく省エネルギー的に不利なので，現在はほと んぞ採用されない。

4 パイプ方式は還管を冷水々温水の 2 本に分離し, この混合損失を防ぐょうにしたもので，複䠕な負荷傾 向の建物で数多く採用されるようになってきた。

しかし，最近の省エネルギーに対する建築界の認識 は，この空面からの大きな冷暖房負荷を建築的手法に よって減少するようになってきた。この傾向は，従来 の大負荷処理を目的としたペリメー夕空調ゾーンの必 要性を減少させ，近い将来，顿々らくファンュイルユ ニット・ペリメータゾーン方式は, オフィス空調の主 流の座を退くことになるだろう。

2.3 二重ダクト方式はVAV方式の先駆であった

二重ダクト方式は, 高度な空調方式の代表として米 国から輸入され，一部の高級オフィスビルあるいは研 究所などの特殊空調棌採用された。「中電ビル（1953 年)」,「新日鉄ビル（1970年）」などがその主要なるの である。

この方式は, 比較的に高価な工事費と運転費から空 調設備の主流としての位置を占めることはなかった。 しかし，この方式の基礎となっている定風量装置の技 術は，次登場するVAV方式にひきつがれ，まった く新しい展開を見せたのである。

大形のエアダクトが冷風用, 温風用と 2 本必要なこ とは，スペースの貴重なビル空調にとっては大変不利 であり，末た混合箱による混合損失る省エネルギー的 立場からは不利な性質で岕った。

2.4 省エネルギー空調の代表的システムで㐫る

\section{VAV方式}

V A V方式の源流は，「三越高松支店（1968年）」に 求めることができる。しかしVAV方式性，当初多く の利点が認められながらもVAVJ式機器の供給が未 完成であったことから，先の採用例はきわわて限られ たものであった。三越高松支店のVAVニニットも二 重ダクト用ミキシングボックスを改造したものであ る。

VAV方式の原形は“開閉できる空”といわれてい るが，この“開閉できる空”がV AV 方式として各種 空調方式の中でひとつの地位を占あるためには，定風 量装置が重要な意味をるっていた。もし，安価で信頼 度の高い定風量装置が存在しなかったとしたら，VA V方式は現在のような地位を占めるには至らなかった だうう。
産業プロセス用换気に定風量装置は古くから用いら れていたが，空調設備として多く使用されるようにな ったのは，二重ダクト方式以降である。この二重ダク 卜方式の温度制御原理は, 定風量変温度であり, 変風 量定温度のVAV方式とはまったく逆のものである が，その機構としての定風量装置は共通のもので西。 た。

そして1971年以降, VA V 用機器の供給態勢が確立 してから，VAV方式はそのシェアを急速に拡大して いった。それは，その省エネルギー性，個室制御性， 低廉な工事費などが高く評価されたためである。今や V A Vは省エネルギー空調の代表的方式のひとつとな っている。

わが国に和けるVAV方式のプロトタイプとしての 三越高松支店が竣工してからすでに12年を経過した。 表 1 の前半 9 例にはVAV方式はなったく採用されて いない。しかし, 後半 8 例中には $1 / 3$ 強の 3 例がV AV 方式を採用している。そして，この傾向はますます增 加している。

\section{3. ユニタリー方式の登場}

3.1 業界の再編成を促すユニタリー・システム

空調方式を大きくらたつに大別すると，中央空調方 式とニニタリー（パッケージ）方式に分けることがで きる。従来，大規模建物は，すべて中央方式によって 空調され, ニニタリ一方式は住宅艺の他の小規模建 物, または大規模建物のごく一部に補助的飞採用され るにすぎなかった。

しかし，最近，このニニタリ一方式が大規模建物に 全面的比採用される場合が現われてきた。「自治医科 大学（1975年)」,「住友生命名古屋ビル（1976年)」な どがその代表で岕る。各種ユニタリ一方式のうちで, 最近とくに注目されているのは, 水熱源小形ヒートポ ンプによるクローズドループ方式と架気熱源ヒートポ ンプによるウォールスルー・ユニット方式である。こ の 2 方式の意味することは，建筑界にとってきわめて 重大である。それは，この 2 方式が，従来になくプレ ハブ化されたもので方り，その設計作業は機器の選択 之配置のみで㐫り, その施工は機器の納入之設置のみ となる。極言すれば, 從来的な設備設計技術者, 設備 施工者を不要とするものなのである。

ユニタリ一方式の主要機器であるパッケージュニッ トは，わが国では1951年，ダイキン工業により量産化 された。以来，この方式は大メーカーをバックにその シェアを着実に拡大しつつある。

3.2 パッケージ形空調機の登場 
わが国で，パッケージュニットが空調設備に打ける 一つのシステムとして登場するようになったのはいつ からのことであろらか。空気調和・衛生工学便覧の目 次に取り上げられ，節として数ぺージにわたる記述が なされたのは，第 9 版 (昭和50年)，1975年からのこ とである。米国の ASHRAE Handbook にシステム として登場したのは，1973年版からである。

機器としてのパッケージュニットが，すでに長い箺 績をもち, 空気調和・衛生工学便覧, ASHRAE Handbook などにも機器として以前よりすでに詳細に記述 されたのに反し，このように一つの空調方式として取 り上げられたのは比較的最近のことなのである。

"The History of Room Air Conditioners" (E. Macleod: ASHRAE Journal, July 1976) によると, 米国においてはすでに1920年代の中ごろからパッケー ジュニットの開発が進められている。

その後, 1929年にパッケージュニットの市販が開始 された。初期の機種は自立式のコンソール形で, 水冷 凝縮機・ベルト駆動圧縮機から成り, その容量は 3,600 〜11,000 BTU であったといわれている。

ウィリス・キャリアの伝記（マーガレット・インケ ルス：空気調和の父 Aug・1957）によると，快感空 調としての空調設備の最初の有力な市場は映画館であ ったとされている。1920年代の初めまで，いわゆる空 調は印刷工場・織物工場・ゴム工場・食品加工工場な ぞの生産用空調が主体で，人を対象とした快感空調は ごく限られたものであった。しかし，1922年にロサン ゼルスのグラウマンスメトロポリタン劇場に, ローガ ソ・ルイスによって空調設備が完成し，夏の興行に大 きな成功を收めて以来, 劇場空調は急速な普及を示し た。1925年, ニューヨークのリボリ一劇場にキャリア 社が本格的空調設備を設置して以来，1930年までにキ ヤリア社だけでも総計 300 に達する劇場用の空調設備 を完成している。

話が少し横道にとれたよらであるが，実はこの劇場 空調の隆盛とパッケージュニット方式には深い関係を 見いだすことができるのである。それは，この最初の 快感空調が大空間を目的とした大形冷凍機によるいわ ゆる中央式であったといらことでめる。もし，この快 感空調が劇場でなく住宅などの小空間を主体として開 発され発展してきたとしたなら，预そらくパッケージ ユニット方式の現状は大分変ったものになっていたは ずである。

\section{3 不評に終ったパッケージュニット}

さて，空調設備は今述べたように一流劇場の標準設
備となっていったが，また夏に客寄せを必要とするデ パートやレストランなどにもそれは急速に普及してい った。そして当然のことながら, 事務所建物への進出 も期待されるよらになってきた。

しかし, 事務所建物に拉ける空調は, 劇場・デパー トなどの空調とはいささかその様相を異にしている。 劇場・デパートなどの大空間空調に対して, 事務所建 物のそれは小空間空調, いわゆる個室空調である。ま た当時のニューヨークやシカゴなどに和ける代表的事 務所建物は超高層建築であった。たと觉ば，当時を代 表するであろら85階建のニューヨークのエンパイアス テートビルは1931年に竣工している。このよらな事情 から, 当時すでに一般化していた劇場の中央式による 空調設備を，そのまま当時の事務所建物の主流である 個室を主体とする高層事務所建物に適用するには，多 くの困難があった。その困難の主なものが，個室制御 性能と中央装置からの風道の処理にあったであろらこ とは，今日のわれわれにも容易に想像のつくところで ある。そして，これらの問題点を克服する空調方式と して，まずハッッケージュニット方式が検討されたこと も当然の成行きである。

しかし前に述べたよらに，米国においてパッケージ ユニットの市販が開始されたのは1929年のことなので ある。おた，パッケージュニットが技術的な完成をみ たのは1930年代もその後半であった。したがって当 時, 事務所建物に採用された個室制御用のパッケージ ユニットはその初期のものであり，形も大きく，発生 騒音も高く, 故障も多く, 事務所用の空調設備として はほとんど使用不能で，まったくの不評に終ったとい われている。

このよらな決定的な不評が，新しいシステムの発展 にとってどのような意味をもつものであるかを，われ われは多くの実例から知っている。それは，根強い偏 見として，システムの正しい評価の妨げとなるのであ る。一般建物空調の分野で今日まで存在するパッケー ジュニットに対する根強い偏見は，このころ作られた ものと考觉られる。

このよらなパッケージュニットの不評から, 劇場そ の他の大空間空調で高い評価を受けていた中央式を， 高層事務所建物にも適用しようとする努力が開始され た。たとえばすてでに述べたキャリア社のインダクシ ョン・ュニットの開発などがその顕著な成功例といえ るだろら。“品気調和の父”には, 最初のインダタショ ン・ユニットが1930年 3 月に設置され，1934年末 に23の建物がこれを採用したと記されている。インダ 
クション・ユニットは以来多くの改良が加えられて急 速に普及し，米国に持ける高層事務所建物の95\%は， このシステムによるといわれるに至った。

また，このほかにも個室空調のための多くのシステ ムが開発されていったが，それらは現在普及している ターミナル・リヒート方式, 二重ダクト方式, ファン コイル・ユニット方式，VAV方式などである。しか し，これらのシステムのすべては中央熱源方式で，パ ッケージュニットによるものではなかった。一般建物 空調にとって, パッケージュニットはすでに忘れ去ら れた存在として最近に至ったのである。

\section{4 パッケージュニット方式の登場}

一方, 中央式の華々しい発展と並行して, パッヶー ジュニットもまた驚くべき発展を遂げていたのであ る。それは，この中央式の採用が絶対に不可能な車 両・住宅・自動車などの分野に沶いてであった。

すでに述べたように，米国に沶いて第二次世界大 戦前までに年産 131,000 台に達したパッケージュニ ットの生産は, 戦後1946年の 27,000 台から 1950 年の 1, 000, 000台, そして, 1968年は4, 000, 000台に達して いた。また製品はより小形化し，より軽量化し，より 取扱いが容易となりより安価なものとなってきてい た。この間の事情は, 多少時間的・量的なずれはあっ ても，わが国でもまったく同一の経緯をたどってい た。たとえば，昭和 32 年 (1957年) に7, 432 台であっ たパッケージュニットの生産は, 表 2 に示すように昭 和43年 (1968年) には 124, 658 台に増加している。ま た，そのデザインが急速に洗練されてきているのも， その事情は米国の場合とまったく同一であった。

しかし，この飛躍的なパッケージュニットの発展 は, 一般建物空調とは別の世界の出来事だったのであ る。パッケージュニットはその生産体制も販売体制も 一般建物空調のものとは別ものであった。一般建物空 調は受注生産であり, 専門の空調設備設計者・施工者 によって採用され，工事が進められていたのに対し， パッケージュニットは大量生産品であると同時に, そ の多くは最終需要者に直接に売られるものであった。

このように，一般建物空調とは異なる分野で洗練さ れ量産化されたパッケージュニットが，一般建物空調 に対する一つのシステムとして再び登場するわけであ るが，その時期は意外に遅く，すでに述べたよらにご く最近の出来事であった。そして, その最大の原因 は, その初期のパッケージュニットに対する根強い不 信感であったのではなかろらか。また，この偏見とも いえる不信感をより根強いものにしたのは, 建物空調
表 2 パッケージュニット国内向出荷実績

\begin{tabular}{|c|c|c|c|c|}
\hline \multirow{2}{*}{ 年度(昭和) } & \multirow{2}{*}{$\overbrace{[\text { 台] }}^{\text {生産台数 }}$} & \multicolumn{3}{|c|}{ 生 産 金 額 } \\
\hline & & [百万円] & 指 & 数 \\
\hline 32 & 7,432 & 5,062 & & 00 \\
\hline 33 & 7,564 & 4,453 & & 88 \\
\hline 34 & 10,510 & 4,841 & & 96 \\
\hline 35 & 21,094 & 9,688 & & 192 \\
\hline 36 & 33,098 & 14,980 & & 297 \\
\hline 37 & 40,999 & 16,121 & & 321 \\
\hline 38 & 42,233 & 16,948 & & 335 \\
\hline 39 & 58,474 & 24,198 & & 479 \\
\hline 40 & 39,202 & 15,043 & & 298 \\
\hline 41 & 45,830 & 16,595 & & 328 \\
\hline 42 & 72,273 & 26,290 & & 520 \\
\hline 43 & 124,658 & 42,877 & & 848 \\
\hline
\end{tabular}

表 3 空気調和・衛生工学会賞を受賞した空調設備

\begin{tabular}{|c|c|}
\hline $\begin{array}{l}\text { 年 度 } \\
\text { (昭和) }\end{array}$ & 建 \\
\hline 43 & パレスサイドビル＼cjkstart国立劇場 \\
\hline 44 & 日本不動産銀行本店 \\
\hline 45 & $\begin{array}{l}\text { 霞が闦ビル 大阪㕌生年金会館 } \\
\text { 北海道庁本庁舎 }\end{array}$ \\
\hline 46 & $\begin{array}{l}\text { 全共連厚木事務所センター＜wide>伊藤忠ビル } \\
\text { 大阪センタービル }\end{array}$ \\
\hline 47 & - \\
\hline 48 & 日本 I BM本社 \\
\hline 49 & 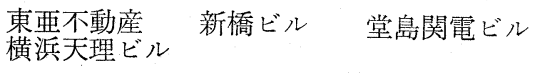 \\
\hline 50 & $\begin{array}{l}\text { 大阪国際ビル ～大阪大林ビル } \\
\text { 自治医科大学＜wide>～}\end{array}$ \\
\hline 51 & $\begin{array}{l}\text { 東京海上火災保険(株)＼cjkstart新宿三井ビル } \\
\text { 住友生命名古屋ビル }\end{array}$ \\
\hline
\end{tabular}

注）太字はパッケージュニット方式によるもの

におけるすでに確立した設計，施工体制であるともい えるだろう。情緒的には設計・施工者の潜在的な恐怖 感, あるいは嫌悪感といったものも無視することはで きない。

表 3 は, 最近10年間に空気調和・衛生工学会賞を受 賞した空調設備の一覧である。これらが必ずしもわが 国の空調設備の動向を正しく示したものであるとはい えないかも知れないが，少なくともわが国の空調設備 の前衛をらかがい知ることはできるであろう。

表 3 によると，そのほとんどが中央式による空調で あるが，昭和50，51年 (1975，1976年)，その末尾に は 2 年続けてパッケージュニット方式による二つの大 
形建物が登場してくる。

\section{5 水熱源ユニタリヒートポンプ方式}

前節で述べた学会賞受賞作品である自治医档大学, 住友生命名古屋ビルなぞのパッケージュニット方式 は，此較的大形のパッターージュニットを各空調ゾーン ごとに配置して大形建物の空調を行うシステムで, 従 来の中央式と対比すればその空調機（エアハンドリン グユニット)をパッケージュニットに置き換克, 冷谏 機設備を省略したものと考光ることがでさる。

このゾーンパックージニニット方式に対し，ターミ ナルパッケージュニット方式とでる称すべきシステム が最近急速な普及を示している。このシステムは一般 に小形ヒートポンプパッケージニニットルよって構成 され, 水熱源によるものと空気熱源によるものとがあ る。

水熟源によるものは，水一空気ヒートポンプュニッ ト (Water-to Air Unitary Heat Pump) として1970 年に ASHRAE Guide に初めて記述された。しかし， "Energy Conservation Unitary System" (L. Kendric, J.P. Soule: ACHV, June 1969) によると, すでに 1959年ころからフロリダで，なた1963年ころからカリ フォルニアで使用されたといわれている。米国で一般 に紹介されたのは，1967年の ASHRAE Exposition に和いてであった。

この装置に関する特許は，1955年に米国において取 得されている(特許 №.2715514，2715515，考案者，W. S.Stair，所有者 York Corporation)。わが国ではM $\mathrm{Y}$ 式熱ポンプ冷暖房装置 [柳町政之助：今後の空気調 和装置について（第 $1 \sim 3$ 報）, 空気崕和・衛生工学, 43-1 (昭44-1)], 小形室内ヒートポンプニニット方式 〔高田俱之：ヒートポンプニニットによる細分化空調 方式, 冷潗, 12 (1971)], ユニット形ヒートポンプ方 式〔川出盛也：ユニット形ヒートポンプ方式空気調和 機, 配管, 2(1972)」として一般に紹介された。

\section{6 空気熱源ユニタリヒートポンプ方式}

空気熱源ユニタりりヒートポンプパッケージによるパ ッケージュニット方式は, 前節で述べた水熱源ユニタ リヒートポンプパッケージを空気熱源ュニタリヒート ポンプパッケージに置き換えたものである。したがっ て, 熱源水配管が不要となり, 設計, 施工ともに著し く箁略化されることがこのシステムの最大の利点とな っている。

一力，暖房を電熱その他の手段によらない場合は， 空気熱源ヒートポンプニニット方式であるために適用 可能地域に大きな制約があり，わが国ではほぼ関東以

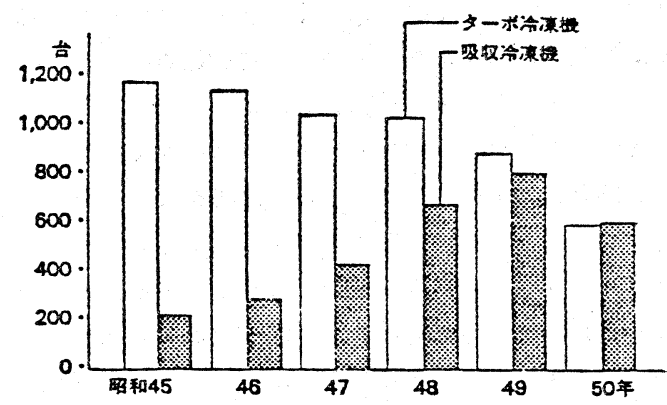

図 1 . 冷凍機国内向出荷実績

南の太平洋側諸地域がその 適用可能地域となってい る。また，各ユニットが水配管などで接続されていな いため，熱回収あるいは蓄熱による排熱の再利用につ いても大きな制約がある。各ユニットが直接に熱源用 の等気を必要とすることも，建物に適用する場合の大 きな制約となっている。しかし，これらの制約にるか かわらず，このシステムはその簢略さからその採用は 急速に增加するものと考えられる。

空側部分に設置された空気熱源ユニタリヒートポン プは，一般にウォールスルーニニット（Wall through Unit）と呼ばれている。

\section{4. 空調用熱源システムの変遷}

\section{1 吸收式冷凍機の隆盛}

冷凍機, ボイラーなどの空調用熱源システムは, 戦 前からの技術を継承した電動式冷凍機（ターボ，レシ プロ）と石炭焚ボイラー（蒸気, 温水)、にはじまり, 1955年前後から，ボイラー然料のそのほとんどは液体 燃料（重油）に変換されていった。

しかし，この重油の大量燃焼は硫黄酸化物による大 気污染を招来した。この污染防止を目的とした全電気 方式によるオフィスビルはこの頃より数多く登場す る。「福岡NHK（1960年）」「広島NHK（1960年）」, 「中電ビル (1963年)」などである。

そしてこれらの全電気式が，より一般化され洗練さ れて登場するのが熱回収方式で「ＩＢM本社ビル （1971年)」，「ヤクルトビル（1972年)」，「東京三和ビ ル（1973年)」，「東京海上火災ビル（1974年)」など， その使用例は増加していった。

一方，クリーン・エネルギーとしてのガスは高く評 価され，1967年にガス焚二重效用吸収冷湅機が市販さ れてから，ガス泠房は急速に普及していった。とくに ガスの季節需要を平準化する目的で，夏季割引料金が 採用されたことも，この普及に拍車をかけることにな った。そして1976年, 図1 亿示すように生産台数に标 
いて吸収冷凍機はターボ冷凍機をしのぐに至った。

\section{2 最初のヒート・ポンプ空調}

ヒートポンプによる冷暖房の可能性についてわが国 に亦忷る最初の論文は, “燃料節約の一策として冷凍 機を暖房機として流用するの議”(「工業の大日本」 1926年 6 月工学博士大塚要）だとされている。この論 文は，当時の冷暖房関係技術者汇強い影響を与え，同 年 8 月に「暖房冷蔵協会誌」(空気調和衛生工学会誌 の前誌)に再揭載された。

この論文は，ヒートポンプの原理についての巧妙な 説明と, 排熱回取式空気熱源ヒートポンプ冷䁔房方式 の提案と，その経済性の検討からなる簡単なるのでめ る。もちらん, この論文の前提として, カルノ一 (1796〜1832 フランス) のヒートポンプ冷暖房につい ての理論があったのであるが，この論文を契機とし て，わが国に和けるヒートポンプ空誳の実用化が発足 したといえるだろら。

わが国最初のヒートポンプ式冷暖房装置としては, 1932年に完成した村山邸を挙げることがでさる。この システムは柳町氏の設計になるもので，木造 2 階建 $150 \mathrm{~m}^{2}$ の住宅に対して，3.5kW の電動アンモ二ア冷凍 機を使用したものであった。

特筆すべきことは，1937年に二つの大規模建物が， 京都市に同時にヒートポンプ空調により完成したこと で岁る。一つは京都電灯株式会社本社ビルで, 地上 8 階地下 1 階鉄骨鉄筋コンクリート延 $10,000 \mathrm{~m}^{2}$ の建物で ある。また一つは宇治電ビルで地下 1 階地上 9 階延 $12,000 \mathrm{~m}^{2}$ の建物である。

京都電灯ビルの空調は柳町氏の設計, 宇治電ビルは 東洋キャリアの設計で㟧った。ともに, 電動ターボ冷 凍機を使用し，井水による水熱源ヒートポンプ方式で める。そして，このヒートポンプ式空譋は，当時とし ては，世界最大級のものとされている。

その後, この技術は第 2 次世界大戦により一時中断 したが，戦後再開され，この井水を熱源とするヒート ポンプ方式は急速に増加していった。良質で豊富な井 水が得られる場合，この茾水熱源ヒートポンプ空調は 一般の空調方式と比較して，十分競合しらるもので， 東京, 名古屋, 大阪学中心として, その設置例は, 1971年までの調査によると，全国で17,000R Tに達し ている。

\section{3 地下水枯渴之大気污染}

しかし，1950年代の日本経済の急速な発展は，市街 地における井止の大量没み上げを招来し，その結果， 市街地に打いては, 并水の水質悪化, 枯渴をもたらし
1962年共水の没み上げ規 制(「建築物用地下水の採取 の規制に関する法街」1962年 5 月 1 日）が害施され， 以降市街地の瑟物に执いては, 井水熱源ヒートポンプ 空罗の採用は，ほとえど不可能となった。

その結果，呅気熱源によるヒート・ポンプの研究が 進められ，1957 年にはNHK福岡放送会館（征 4,000 $\mathrm{m}^{2}$ 福岡市）が空気熱源ヒートポンプ方式により完成さ れている。このシステムの設計る柳町氏で，当時きわ めて斬新な方式であった。しかしこの時代において は, 一般の空䏱方式と比較して, 空気熱源方式は性能 的にも経済的にも競合しうるものでなく，その採用は ごく一部の茟物に限られていた。

だが，日本経済のな永急速な発展は，ついに，市街 地に打ける大気污染をもたらし，これが重大な社会問 題となるに及んで，1968年 6 月大気污染防止法が施行 され，重油然㜔に対し各種の規制が実施された。その 結果，1970年に至り，大気污染を伴わず，省エネルギ 一的な空崕に対する社会的な要求が高まり, 空気熱源 ヒートポンプ方式，排㓐回収ヒートポンプ方式による 空調がここ数年急速に増加して今日に至っている。

排熱回収水熱源ヒートポンプ空詪は，すでに10数年 前から実施例が㐫るが，我躍的に増加したのは1970年 以降である。これら多くのものは，ダブルハンドル・ コンデンサ笚段ターボを採用し，蓄熱槽を利用して冷 房負荷，暖房負荷の均衡をはかっている。

1974年のターボ冷凍機年産台数 840 台のらち, 約 10 \%がヒートポンプ用として使用されていると推定され る。

空調用大形空気熱源ヒートポンプは，初期の実施以 来，10数年の経験と改良により，今日，技術的に一応 の信頼を高めつつあり, 社会的な要請も加わり, その 採用例が最近急速に増加してきている。とくにスクリ ュー式コンプレッサーを使用したるのが注目を集めて いる。

\section{4 ヒートポンプ化するユニタリ一空調方式}

パッケージ形ェアコンは，国産機として最初に1951 年, ダイキンから発売された。以降，1952年三菱電 機，1953年日立，1954年三菱重工と続き，1974年には 年産 250,000 台に達している。このパッケージ形ェア コンで水熱源ヒートポンプ方式によるものは，1954年 ダイキンから発売されたが，井水揚水規制などによ り，大きな進展はなかった。

一方，空気熱源ヒートポンプ方式によるパッケージ 形は，1960年同じくダイキンから発売され，1970年ご ろより急速にそのシェアを拡大し，1974年には，全パ 
ッケージ形ェアコン生産数の $17 \%$ を占めている。

このルームエアコンディショナーのらち, ヒートポ ンプ方式の占める率は, 1969年で約 $1 \%$ であったが, その後急速にそのシェアを拡大し，1974年には $25 \%$ に 達している。

\section{5. 空調システムの将来}

\section{1 個別システムはどらたるか}

熱源システムを決定する主な要因は，(1)空調負荷／ (2)空調システム/(3) 2 次エネルギー・システムの 3 項 目である。そして, これらの要因は, 次のような傾向 を示している。

（1）冷房負荷増加の傾向を示す空調負荷

空調負荷の構成要素である内部負荷は, 建築の高級 化にしたがって年々増加の傾向をたどっている。これ は, いいか觉れば建物の冷房負荷は増大しているとい うことになる。また, 建物は大型化し, 断熱技術も普 及し暖房負荷は減少している。その結果, 一般の建物 では暖房負荷に対する冷房負荷の割合が相対的に増加 する傾向をたどっている。

(2) 個別化の傾向を示す空調システム

空調システムは, その発祥の初期から常に個別化を 指向して発達している。特に, 社会・経済の多様化の はげしい現在, この傾向はますます顕著だ。

（3）全電力化の傾向を示す 2 次エネルギー・システ 么

利用エネルギー・メディアとしての 2 次エネルギー は, 電力, 都市ガス, 石油がその主要なるのである が, 過去数 10 年の間, 人類のエネルギー需要は 10 年に 2 倍となる増加を示してきたが, 電力の需要は 2.7 倍 の増加となっている。この傾向がつづくとすれば将 来, 2 次エネルギーはすべて電力化してゆくものと考 えられている。

さて, 個別システムのシステム決定の 3 要因が，こ のような傾向を示すとすると, この傾向に対し, すっ とも適切な熱源システムとして, 小型ヒート・ポンプ 方式を挙げることができる。この小形ヒート・ポンプ 方式は, システム決定の 3 要因に対して, 次のような 適応性を示しているからだ。

（1）第 1 の要因である冷房負荷増加の傾向に対し て, ヒート・ポンプ方式はその本来の特性から, 空気 熱源, 熱回収ともに優れた対応を示し, 省エネルギー 的にも有利な方式となっている。

(2) 第 2 の要因である個別化の傾向に対しては, 本 来的に個別化された小形ヒート・ポンプは優れた対応 を示し，特に省エネルギー的運転を可能にしている。
（3）第 3 の要因である全電力化の傾向は，暖冷房と もに電動力によって駆動される小形ヒート・ポンプに とっては同一の傾向で，その普及の有利な条件となっ ている。

このような理由から，個別システムに対する空調熱 源方式としては小形ヒート・ポンプ・ニニットによる 省エネルギー・・ステムの発展が大きく期待されてい るのである。

\section{2 地域システムはぞうなるか}

地域熱源システムの推進要因として次の 3 項目が挙 ゲられている。

(1)都市エネルギー・システムの反省ノ(2)都市排熱の 増加／(3)社会資本の充実

（1）都市エネルギー・システムの反省とは，先に述 べた 2 次エネルギー・システムの全電力化傾向に対す る抵抗要因で，今後の電源開発低対する悲観的な予 測, 発送電によるエネルギー損失などから提起された 電力万能の都市エネルギー・システムに対する反論 で，この反論では，将来の都市エネルギー・システム は動力源としての電力, 高温熱源としての都市ガス, 低温熱源としての蒸気・温水によって都市エネルギー はネット・ワークされることが望ましい形式と考党て いる。

（2）近代都市に抬ける都市排熱は年々増加し，現 在, その主要なものは発電所排熱とごみ処理熱であ る。そして，この排熱のもっとも有効な利用法と考克 られているものが都市の冷暖房・給湯である。この場 合, その技術としては, 熱併給発電, ごみ焼却ボイラ 一など各種のトータル・エネルギー・システムが考克 られている。

（3）社会資本の充実は，わが国にとって，重要な国 家的課題のひとつである。そして, 地域熱源システム は, そのひとつとしての位置を占め, その充実が期待 されている部門でるある。

さて，このような 3 項目の要因によって推進される 地域熱源システムは都市排熱を有効に利用する各種の 高効率のトータル・エネルギー・システムとなるだろ 亏。

\section{3 太陽熱利用システムはどらなるか}

各種の太陽熱利用技術の中で, 冷暖房, 給湯への利 用が他の利用分野に比較して容易なのですでに太陽 熱冷暖房・給湯は技術的には十分可能な段階に達して いる。そして, 現在その普及の最大の阻害要因は装置 の経済性にあるといわれている。しかし，この経済性 の真の要因は太陽エネルギーの偏在によるものだろ 
う。市街地の太陽は, その高密度化した人口, 建物に

とってはすでに希少な環境要素で, 冷暖房用エネルギ

一として利用するには, あまりに貴重すぎるェネルギ 一となってしまった。そのため, 市街地では, その経 済性は将来とも本質的に成立しがたい困難な課題とな っている。

一方, 太陽が相対的に豊富な郊外, 僻地, 特にエネ ルギー・システムのネットワークからはずれた地域に 対しては有望な省エネルギー・システムで，このよう な地域の建物は，今後なんらかの太陽利用システムが 必ず採用されることになるだろら。

\section{4 総合的に眺めると}

すべて多様化している現代では，その技術も多様化
し，その多くのものは多重的に併存していく。

空調用熱源システムも，このような意味で多種類の 方式が多重的に併存し, その立地条件, 使用目的, 安 全性, 省エネルギー性などにより選択, 陶汰されてい くだろう。その結果,

・個別システムには各種の小形ヒート・ポンプ・シ ステム

・地域システムには各種都市排熱利用トータル・エ ネルギー・システム

・郊外・僻地には各種太陽システム がその主流となり，互いに影響を与学ながらより洗練 されたシステムへと発展していくと考劣ることが，む っとも常識的で穏当で無難な答えではなかららか。

\title{
Tendency and Future of Air-conditioning Systems for Buildings
}

\author{
Akira ISHIFUKU \\ (Nikken Sekkei Ltd)
}

SYNOPSIS : - This report gives an outline of the tendency and the future of air-conditioning systems for buildings in Japan.

Concerning the central air-conditioning systems, this report referres to induction unit systems, fan-coil unit systems, dual duct systems and VAV systems. These systems influenced each other and have occupied present positions.

Concerning the unitary systems, this report referres to the appearance of the packaged air-conditioners on markets and to the development of the unitary systems.

Systems of heating and cooling source for air-conditioning have changed depending on their economy and influence to enviromental pollution. This report summarizes history of the systems of heating and cooling source. 